ElementerIs: Jurnal Ilmiah Pendidikan Dasar Islam

Volume 2 Nomor 1 Mei 2020

e-ISSN: 2655-6324

\title{
PENERAPAN STRATEGI CATATAN TERBIMBING UNTUK MENINGKATKAN PEMAHAMAN MATA PELAJARAN IPS KELAS IV MI ISLAMIYAH PAKEL MONTONG TUBAN
}

\author{
Dewi Niswatul Fithriyah ${ }^{1}$, Moh Nur Fadlil2, Nur Nafisatul Fithriyah ${ }^{3}$ \\ Pascasarjana UIN Sunan Ampel Surabaya \\ e-mail: $\underline{1}$ dewiniswatulfithriyah@gmail.com, 2 fadlil.nur0502@gmail.com. \\ 3nurnafisatulfithriyah@gmail.com
}

Diterima: 2 Juli 2020 I Direvisi: 15 Juli 2020 I Disetujui: 16 Juli 2020 (C) 2020 Pendidikan Guru Madrasah Ibtidaiyah Fakultas Agama Islam Universitas Islam Malang

\begin{abstract}
Abstrak
Research is motivated by the low student learning process and also the weak learning process that is still centered on the teacher. Teaching and learning activities that are always discussed by the teacher will result in low student learning activities in school. The subjects in this class action research were grade IV MI Islamiyah Pakel Montong Tuban students. As an effort that can be done to overcome these problems, then this is by implementing a guided note strategy. Through a record of guided strategies, students will be asked to participate in teaching and learning activities and students will be better prepared and able to discuss the material being studied in action, observation, and reflection. The results showed that the application of guided strategy notes to the pre-literate epoch material of social science subjects was carried out smoothly and very well. Proof can also be known from the value generated by students in working on LK outlining the contents of the text that discusses the history of preliteracy and also describes lessons that can be drawn from the history of pre-literate community life with the percentage of classical learning completeness $66.6 \%$ in the first cycle and $83,3 \%$ in the second cycle.
\end{abstract}

Keywords: Strategy, Guided notes, Increased understanding.

\begin{abstract}
Abstrak
Penelitian didorong oleh rendahnya proses belajar siswa dan juga proses belajar yang lemah yang masih berpusat pada guru. Kegiatan belajar mengajar yang selalu berpusat pada guru akan mengakibatkan rendahnya aktivitas belajar siswa di sekolah. Subjek dalam penelitian tindakan kelas ini adalah siswa kelas IV MI Islamiyah Pakel Montong Tuban. Sebagai upaya yang dapat dilakukan untuk mengatasi masalah tersebut, maka hal ini dengan menerapkan strategi catatan terbimbing. Melalui strategi catatan terbimbing, siswa akan diminta untuk berpartisipasi dalam kegiatan belajar mengajar dan siswa akan lebih siap dan dapat mendiskusikan materi yang dipelajari dalam tindakan, observasi, dan refleksi. Hasil penelitian menunjukkan
\end{abstract}

This work is licensed under Creative Commons Attribution Non Commercial 4.0 International License Available online on: http://riset.unisma.ac.id/index.php/je 
bahwa penerapan strategi catatan terbimbing dalam materi zaman pra-aksara mata pelajaran IPS dilakukan dengan lancar dan sangat baik. Bukti juga dapat diketahui dari nilai yang dihasilkan oleh siswa dalam mengerjakan LK menguraikan isi teks yang membahas sejarah pra-aksara dan juga menggambarkan pelajaran yang dapat diambil dari sejarah kehidupan masyarakat pra-aksara dengan persentase dari ketuntasan belajar klasikal 66,6\% pada siklus pertama dan 83, 3\% pada siklus kedua.

Kata kunci: Strategi, Catatan terbimbing, Peningkatan pemahaman.

\section{Pendahuluan}

Pendidikan IPS merupakan adaptasi ataupun penyederhanaan dari disiplin ilmu-ilmu sosial dan humaniora, serta kegiatan dasar manusia yang diorganisasikan dan disajikan secara ilmiah dan pedagogis/psikologis untuk tujuan pendidikan. Sedangkan pengertian kedua pendidikan IPS adalah seleksi dari disiplin ilmu-ilmu sosial dan humaniora, serta kegiatan dasar manusia yang diorganisasikan dan disajikan secara ilmiah dan psikologis untuk tujuan Pendidikan (Nu'man Sumantri, 2001:92). Ilmu Pengetahuan Sosial (IPS) merupakan salah satu mata pelajaran yang ada di sekolah dasar. Berdasarkan fakta di lapangan, pemahaman mata pelajaran IPS yang membahas tentang materi zaman pra-aksara peserta didik kelas IV MI Islamiyah Pakel Montong Tuban ini masih sangat dibawah standart. Ketika guru menjelaskan sebuah materi kehidupan masyarakat pra-aksara, peserta didik hanya mampu memahami konsep dasar tentang kehidupan masyarakat pra-aksara saja dan belum mampu mengkorelasikan dengan kehidupan yang real. Seharusnya, guru mampu meningkatkan kemampuan pemahaman ke level berikutnya yaitu pemahaman penafsiran. Seharusnya guru mampu mendorong peserta didik untuk mengaitkan sejarah zaman pra-aksara dengan kehidupan yang real dengan peserta didik mampu untuk lebih bersyukur atas kehidupan yang dijalaninya saat ini dan juga adanya persediaan bahan-bahan pokok yang bisa didapat dengan sangat mudah dibandingkan dengan pada kehidupan masyarakat pra-aksara. Guru masih belum mampu menggiring peserta didik untuk memiliki kemampuan pemahaman tingkat ekstrapolasi, dimana dengan hanya melihat video tentang kehidupan masyarakat pra-aksara peserta didik sudah mampu mengambil hikmah yang dapat dipelajarinya. Hal ini membuktikan bahwa peserta didik masih belum mampu mencapai pada tingkat kemampuan pemahaman penafsiran dan tingkat pemahaman ekstrapolasi.

Peserta didik kelas IV MI Islamiyah Pakel Montong Tuban yang berjumlah 30 peserta didik ini, 16 peserta didik yang mampu memahami sejarah zaman praaksara. Hal ini diketahui melalui pemenuhan KKM. Nilai KKM untuk mata pelajaran 
IPS adalah 70. Sedangkan dari 30 peserta didik hanya ada 16 peserta didik yang mampu memenuhi nilai KKM yang telah ditentukan dan 14 peserta didik lainnya masih belum mampu mencapai nilai KKM yang telah ditentukan. Hasil wawancara kepada peserta didik dan juga kepada guru menunjukkan dalam proses pembelajaran materi kehidupan zaman pra-aksara, guru tidak menerapkan strategi yang sesuai untuk meningkatkan pemahaman peserta didik. Selain itu guru menggunakan strategi ceramah saja dan tidak menggunakan sumber yang bervariatif. Oleh karena itu, penerapan strategi catatan terbimbing sangat efektif untuk meningkatkan pemahaman peserta didik. Strategi catatan terbimbing merupakan strategi yang menekankan pada peningkatan kemampuan dalam mengambil point-point penting dari teks lisan yang didengar dengan memberikan panduan yang berbentuk kisi-kisi yang berupa pernyataan yang belum sempurna. Dengan strategi catatan terbimbing ini, peserta didik akan mampu memahami materi dengan menangkap poin-poin penting dari materi tersebut dan kemudian dikembangkan menjadi lebih luas.

\section{Metode}

Metode penelitian yang digunakan dalam penelitian tindakan kelas ini adalah model Kurt Lewin yang setiap siklusnya meliputi rancangan, tindakan, pengamatan, dan refleksi (Samsu Sumadayo, 2013:39). Tempat penelitian ini adalah di MI Islamiyah yang terletak di desa Pakel Kecamatan Montong Kabupaten Tuban. Subjek penelitian ini adalah peserta didik kelas IV MI Islamiyah Pakel Montong yang berjmlah 30 peserta didik pada tahun ajaran 2016/2017. Dalam mengumpulkan sebuah data, peneliti menggunakan teknik observasi, wawancara dan tes. Adapun instrumen yang digunakan peneliti sebagai berikut:

1. Instrument lembar observasi aktivitas guru siklus I dan II.

2. Instrumen lembar observasi aktivitas peserta didik siklus I dan II.

3. Instrumen lembar observasi pemahaman peserta didik siklus I dan II.

4. Format panduan wawancara guru sebelum tindakan.

5. Format panduan wawancara peserta didik sebelum tindakan.

6. Soal uraian tes pemahaman siklus I.

7. Soal melengkapi teks catatan terbimbing siklus I.

8. Soal uraian tes pemahaman siklus II.

9. Soal melengkapi teks catatan terbimbing siklus II.

Setelah data terkumpul, tahapan selanjutnya adalah menganalisis. Data yang dihasilkan dalam penelitian ini, setiap siklus akan dianalisis secara deskriptif 
kualitatif. Untuk menganalisis hasil observasi yang silakukan selama kegiatan belajar mengajar, maka lembar observasi menggunakan rumus:

$$
P=\frac{F}{N} \times 100
$$

Keterangan: $\mathrm{P}=$ Nilai

$$
\mathrm{F}=\text { Skor yang diperoleh }
$$

$\mathrm{N}=$ Skor maksimal

Sedangkan dalam penilaian melengkapi teks catatan terbimbing menggunakan rumus :

$$
\text { Skor: } \frac{\mathrm{B}}{\mathrm{N}} \text { x } 100 \text { (skala 0-100) }
$$

Keterangan: $\mathrm{B}=$ Jumlah jawaban benar

$$
\mathrm{N}=\text { Jumlah soal }
$$

Dalam melengkapi soal uraian menggunakan rumus :

Penskoran: Skore yang diperoleh $\times 100$

\section{Skore maksimal}

Untuk menghitung ketuntasan belajar peserta didik dalam mengerjakan soal melengkapi teks catatan terbimbing dan mengerjakan soal uraian digunakan rumus sebagai berikut :

$$
A=\frac{X}{Y} \times 100 \%
$$

Keterangan : A = prosentase ketuntasan belajar

$\mathrm{X}=$ Jumlah peserta didik yang mencapai KKM

$\mathrm{Y}=$ Jumlah seluruh peserta didik dalam satu kelas.

Dalam penelitian ini yang akan dilihat adalah indikator kinerjanya. Maka diperlukan indikator kinerjanya sebagai berikut: Ketuntasan hasil belajar yang termasuk dalam kategori baik $(>70)$ dari jumlah peserta didik seluruhnya. Nilai rata-rata peserta didik kelas IV MI Islamiyah Pakel Montong Tuban pada mata pelajaran IPS dengan minimal 70. Keaktifan guru dan peserta didik dalam kategori baik (>70) berdasarkan hasil pengamatan guru peneliti dan pengamat.

\section{Hasil Penelitian}

Hasil penelitian penerapan strategi catatan terbimbing untuk meningkatkan pemahaman zaman pra-aksara mata pelajaran IPS peserta didik kelas IV MI Islamiyah Pakel Montong Tuban. Hasil Penelitian Siklus I tahap perencanaan, kegiatan utama yang dilakukan oleh peneliti adalah membuat sebuah RPP yang didalamnya berisi tentang sebuah rencana yang akan dilakukan dalam pelaksanaan pembelajaran, mempersiapkan berbagai media yang akan digunakan ketika melakukan kegiatan belajar mengajar, menyusun lembar observasi aktifitas guru 
dan aktifitas peserta didik, menyusun lembar observasi tingkat pemahaman peserta didik yang meliputi 3 tingkat pemahaman yaitu pemahaman terjemahan, pemahaman interpretasi, dan pemahaman ekstrapolasi, mempersiapkan apersepsi dan ice breaking untuk menumbuhkan semangat peserta didik dalam belajar, menyusun sebuah materi yang akan diajarkan, membuat lembar kerja peserta didik dan teks catatan terbimbing.

Untuk tahap pelaksanaan siklus I hasil observasi menunjukkan nilai 87,5 yang termasuk dalam kategori baik. Sedangkan dari observasi yang dilakukan menunjukan bahwa hasil observasi aktivitas peserta didik menunjukkan nilai ratarata 14,2 yang berada dalam kategori baik. Hasil tes pemahaman peserta didik dalam melengkapi teks catatan terbimbing pada siklus I prosentase belajarnya menunjukkan 67\%. Sedangkan rata-ratanya 67 dan belum mencapai nilai KKM yang ditentukan oleh sekolah. Tetapi peserta didik yang mendapat nilai diatas KKM tersebut sebanyak 20 peserta didik. Hasil tes pemahaman peserta didik dalam mengerjakan soal uraian pada siklus I prosentase belajarnya menunjukkan $66,6 \%$. Sedangkan rata-ratanya 64 dan belum mencapai nilai KKM yang ditentukan oleh sekolah. Tetapi peserta didik yang mendapat nilai diatas KKM tersebut sebanyak 20 peserta didik. Pembelajaran yang dilakukan dalam siklus I yang menerapkan startegi catatan terbimbing belum mampu berjalan dengan sempurna. Hal ini dibuktikan dengan nilai yang dihasilkan peserta didik belu mencapai KKM yang ditentukan sekolah. Hal-hal yang ditemukan dalam pelaksanaan siklus I yang memerlukan perbaikan adalah peserta didik belum mampu belajar dengan fokus, peserta didik masih belum memiliki rasa kepercayaan diri dalam mengerjakan LK, desain pembelajaran yang menerapkan strategi catatan terbimbing yang telah disusun oleh peneliti belum mampu terlaksana dengan maksimal.

Hasil penelitian siklus II observasi yang dilakukan menunjukkan bahwa hasil observasi menunjukkan nilai 96,8 yang termasuk dalam kategori sangat baik. Dari observasi yang dilakukan menunjukan bahwa hasil observasi aktivitas peserta didik menunjukkan nilai rata-rata 17,3 yang berada dalam kategori baik. Hasil tes pemahaman peserta didik dalam melengkapi teks catatan terbimbing pada siklus I prosentase belajarnya menunjukkan 76,6\%. Sedangkan rata-ratanya 77,3 dan telah mencapai nilai KKM yang ditentukan oleh sekolah. Tetapi peserta didik yang mendapat nilai diatas KKM tersebut sebanyak 23 peserta didik. Hasil tes pemahaman peserta didik dalam mengerjakan soal uraian pada siklus I prosentase belajarnya menunjukkan 83,3\%. Sedangkan rata-ratanya 77 dan belum mencapai nilai KKM yang ditentukan oleh sekolah. Tetapi peserta didik yang mendapat nilai diatas KKM tersebut sebanyak 25 peserta didik. 


\section{Simpulan}

Berdasarkan data hasil penelitian dan data yang telah diuraikan, maka peneliti menyimpulkan sebagai berikut: Penerapan strategi catatan terbimbing dengan materi kehidupan masyarakat pra-aksara pada peserta didik kelas IV MI Islamiyah Pakel Montong Tuban pada semester ganjil tahun pelajaran 2016/2017 telah dilaksanakan dengan sangat baik. Hal ini dapat dibuktikan dengan hasil dari dua perbandingan hasil observasi aktifitas guru dan hasil observasi aktifitas peserta didik yang dilakukan pada siklus I dan siklus II. Penjabaran dari kedua aspek tersebut adalah: 1) Hasil observasi aktifitas guru pada siklus I skor ahirnya mencapai 87,5 yang termasuk dalam kriteria baik. Sedangkan hasil observasi aktifitas guru pada siklus II mampu mencapai skor yang lebih baik lagi yaitu 96,8 dan dalam kriteria sangat baik. 2) Hasil observasi aktifitas peserta didik pada siklus I diperoleh rata-rata skor akhir aktifitas peserta didik dalam satu kelas sebesar 21,5. Sedangkan hasil observasi aktifitas peserta didik dalam satu kelas pada siklus II diperoleh rata-rata skor akhir 23,2. Dari kedua hasil observasi aktifitas peserta didik tersebut dapat disimpulkan bahwa aktifitas peserta didik dalam mengikuti kegiatan kegiatan belajar mengajar dari siklus I ke siklus II mengalami peningkatan sebesar 1,7. Data di atas membuktikan bahwa peningkatan yang terjadi pada aktifitas guru juga akan mempengaruhi peningkatan aktifitas peserta didik. Penerapan strategi catatan terbimbing sangat mempengaruhi meningkatnya pemahaman peserta didik terhadap materi zaman pra-aksara mata pelajaran IPS. Hal ini dibuktikan dengan meningkatnya nilai prosentase ketuntasan belajar secraa klasikal yang dihasilkan peserta didik dalam mengerjakan soal-soal bentuk uraian untuk mengetahui tingkat pemahaman yang dimiliki oleh peserta didik. Nilai prosentase ketuntasan belajar secara klasikal dalam melengkapi teks catatan terbimbing yang dilakukan pada siklus I adalah 67\%. Sedangkan nilai prosentase ketuntasan belajar secara klasikal yang dilakukan pada siklus II mencapai 76,6\%. Nilai prosentase ketuntasan belajar secara klasikal dari siklus I ke siklus II mengalami peningkatan sebesar 9,6\%. Hal ini menunjukkan bahwa penerapan strategi catatan terbimbing mampu meningkatkan pemahaman peserta didik terhadap materi zaman pra-aksara mata pelajaran IPS.

\section{Daftar Rujukan}

Arifin, Zainal. (2011). Evaluasi Pembelajaran. Bandung: PT Remaja Rosdakarya.

Gafur, Abdul. (2012). Desain Pembelajaran: Konsep, Model dan Aplikasinya dalam Perencanaan Pelaksanaan Pembelajaran. Yogyakarta: Ombak. 
Dewi Niswatul Fithriyah, Moh Nur Fadlil, Nur Nafisatul Fithriyah

Majid, Abdul. (2014). Pembelajaran Tematik Terpadu. Bandung : PT Remaja Rosdakarya.

Mulyasa H. E. (2010). Praktik Penelitian Tindakan Kelas. Bandung: Remaja Rosdakarya.

Purwanto, Ngalim. (2012). Prinsip-Prinsip dan Teknik Evaluasi pengajaran. Bandung: PT. Remaja Rosdakarya.

Purwanto, Ngalim. (2013). Psikologi Pendidikan. Bandung: Remaja Rosdakarya.

Sanjaya, Wina. (2009). Penelitian Tindakan Kelas. Jakarta: Kencana Prenadamedia Group.

Sapriya. (2009). Pendidikan IPS Konsep dan Pembelajaran. Bandung: PT. Remaja Rosdakarya.

Setyosari, Punaji. (2010). Metode Penelitian Pendidikan. Jakarta: kencana prenada media group.

Setyosari, Punaji. (2010). Metode Penelitian Tindakan dan Pengembangannya. Jakarta: Kencana Prenada Media Group.

Somantri, Nu'man. (2001). Menggagas Pembaharuan Pendidikan IPS. Bandung: PT. Remaja Rosdakarya.

Subhan, Fauti. (2013). Penelitian Tindakan Kelas. Sidoarjo: Qisthos Digital Press.

Sudjana, Nana. (2010). Evaluasi Proses dan hasil pembelajaran. Jakarta: Bumi Aksara.

Suyono dkk. (2012). Belajar dan Pembelajaran. Bandung: PT. Remaja Rosdakarya Offset.

Syaifurahman dkk. (2013). Manajemen dalam Pembelajaran. Jakarta: PT. Indeks.

Wena, Made. (2010). Strategi Pembelajaran Inovatif Kontemporer Suatu Tinjuan Konseptual Operasional. Jakarta Timur: PT. Bumi Aksara.

Widoyoko, Eko Putro. (2011). Evaluasi Program pembelajaran. Yogyakarta: Pustaka Pelajar. 